\title{
The Role of Local People in Improving Education of the Archipelago and Remote Communities of Indonesia
}

\author{
Mohammad Hidayaturrahman \\ Wiraraja University, Sumenep, Indonesia \\ hidayatsahabatkita2016@gmail.com
}

\begin{abstract}
This study aims to explore how far the role of local leaders in improving education in the archipelago and remote areas in Indonesia. This research is also intended to find out the supporting and inhibiting factors to improve the education of fishermen community. This research uses qualitative explanative approach, with data collection through in-depth interviews with local leaders, students, alumni, parents and education managers, and experts in the field of education. Besides the researchers also make direct observations of the object of research, and collect relevant data from institutions related to the field of education. From the research conducted, it was found that local leaders had an important role in improving community education in the archipelago and remote areas. It is known from the rapid growth of educational institutions at various levels in several islands, which is the result of education conducted by local leaders. As for the factors that support the increase is the awareness of the graduates and fishermen community in general to increase their capacity, so their economic life will also increase. While the inhibiting factor is an archipelagic region far from the mainland, so that teachers and educators who are expected to teach in the archipelago are still not met properly. There needs to be a stronger incentive from the government towards teachers and teachers who have specialized in scholarship to be able to work in the archipelago. The government can work together with universities that have attention to education in the archipelago to send alumni teaching in the archipelago. Furthermore, the teachers work with local figures in the archipelago, in carrying out teaching and learning tasks.
\end{abstract}

Key Words: Local character, education, archipelago.

\section{INTRODUCTION}

The educational condition of Indonesian citizens is not yet encouraging. This is at least known from Anies Baswedan's statement at the time of becoming Minister of Education. According to him, education in Indonesia is still in a position that has not been good. There are many things that can demonstrate this, including low quality of education, low education service, as well as low quality of higher education, and low literacy ability of children. automatically, this will have a direct impact on the graduates of basic and higher education (Widodo, 2015: 294).

Education conditions in remote areas and islands are also more apprehensive, both in terms of human resources (educators), facilities and infrastructure, as well as budget improvement of education. SDM educators in the archipelago lacked insufficient numbers, unbalanced distributions, under-standard qualifications, lack of competence, and incompatibility between educational qualifications and the areas under study. It takes the political will of the central government to touch the problems in the archipelago. In the field of education, the budget for dealing with educational constraints in the archipelago should be optimal, for example, school buildings are rickety, roofs damaged, decayed wood, and so on (Prasetyo, Koransindo, January 17, 2016).

The Madura Island is also in a poor condition in terms of education and human resource development. This can be seen from the data released by the Central Bureau of Statistics of East Java Province. Seen from the index of human development (IPM), Sampang IPM was in the number 59.09. The same thing happened in Bangkalan District with IPM 62.06, and Sumenep Regency 63.42. The IPM rate is higher in Pamekasan District, which is 63.98. in general, the human development index (IPM) of districts in Madura is far below the index of human development (IPM) of East Java of 69.74. If seen at the level of education or schooling, then the district in Madura is also still not encouraging. In Kabupaten Sampang, the average level of education does not pass primary school (SD) or the average length of the population attended only four years. As well as other districts, namely Bangkalan and Sumenep regencies, the average length of the schooling population is five years, or the same as not graduating from primary school (www.jatim.bps.go.id).

Most archipelagic areas inhabited by fishermen have been synonymous with poverty and underdevelopment in education. On the other hand, the rate of population growth of the tribal sailors is fairly high. As happened to the Bajo Tribe on Saur Island and Saibus. Poverty that occurs in the Bajo Tribe in Saur-Saibus is a cultural poverty, where the Bajo Tribe on both islands is more due to natural factors, namely the lack of existing natural resources. In addition, poverty is also caused by the 
behavior and attitude of fishermen who are less looking for alternatives from work as fishermen, as well as alternative locations to catch fish (Rahman, 2018: vii).

Interestingly, in terms of education, the population of Sapeken Island is quite advanced, this can be seen from the composition of existing school graduates. The average level of education of the island's residents is High School (SMA) or equivalent. Every year the average student who graduated high school and Madrasah Aliyah (MA) both the school in Sapeken Island and the school out the island as many as 250 people, consisting of 100 graduate SMA, and 150 graduates of Madrasah Aliyah. As for residents who have taken high school, both diplomas and scholars spelled out a lot. Until now the number of residents with diploma graduates as many as 200 people, while the scholars reach 300 people, 15 masters, 1 doctor. the educational progress of the population in Sapeken Island can also be seen from the number of educational institutions that there are quite a lot. Starting from kindergarten to high school and Madrasah Aliyah the number reached 27 schools. while for the lecture, residents of this island go to the cities in Java and Bali, among them Malang, Surabaya, Jakarta and Bandung. There are also those who go to Malaysia and Turkey ${ }^{1}$.

From the description of the background above, it can be explained that the problem to be discussed in this research is, how the role of local leaders, in this case $\mathrm{KH}$. Ad-Dailamy Abu Hurairah in conducting social change, through his educational activities, mainly through the pesantren he built since 1976, namely Pesantren Abu Hurairah.

This research is expected to be a reference that can enrich the source of reference in the study of social change theory and education. That to make social change, education is one of the options that need to be used as a reference. Not only for urban areas, for rural areas, even the archipelago, social change can be successfully done through education, and human resource development.

\section{METHOD}

This research uses explanative eksitanatif approach, that is explaining and describing facts and data obtained during the research, related to social theory that exist. As for the data collection is done by doing direct observation or observation, but also conducted in-depth interviews to various informants associated with the research. Informants interviewed were key informants in this case KH. ad-Dailamy Abu Hurairah and supporting informants, namely the graduates. The data collected is then analyzed and discussed with the theory of actors drawn from various references, both online and offline.

\section{RESULTS AND DISCUSSION}

Sapeken residents have high attention to the education of their children. This can be seen from the great

\footnotetext{
${ }^{1}$ Interview with H. Jailani, UPT Education at Sapeken District Office, May 2, 2018
}

desire of the parents to send their children to the undergraduate level. Although most of them being fishermen but they are still eager to send their children to college in the big cities in Indonesia.

As stated by Mr. Hasan, who daily works as an oncor fisherman $^{2}$. Mr. Hasan sent his son to Surabaya and to Malang to become a scholar at the State Islamic University (UIN) Malang. "Currently my son has become a teacher at a favorite school in Malang, alhamdulillah, although I am only oncor fishermen," he said ${ }^{3}$.

Table 1

Institution of Education in Sapeken Island

\begin{tabular}{|c|c|c|}
\hline No & School & Level \\
\hline 1 & Assakinah & Kindergarten \\
\hline 2 & Nidaul Jihad & Kindergarten \\
\hline 3 & Mujahadah & Kindergarten \\
\hline 4 & Baiturrahim & Kindergarten \\
\hline 5 & Safinatun Najah & Kindergarten \\
\hline 6 & Babussalam & Kindergarten \\
\hline 7 & Muhammadiyah & Kindergarten \\
\hline 8 & Generasi Abu Hurairah & Kindergarten \\
\hline 9 & Al-Ghuraba & Kindergarten \\
\hline 10 & SDN 1 Sapeken & Primary school \\
\hline 11 & SDN 2 Sapeken & Primary school \\
\hline 12 & SDN 4 Sapeken & Primary school \\
\hline 13 & SDN 5 Sapeken & Primary school \\
\hline 14 & SDIT Abu Hurairah & Primary school \\
\hline 15 & SD Muhammadiyah & Primary school \\
\hline 16 & Ml Abu Hurairah & Madrasah Ibtidaiyah \\
\hline 17 & MI Nurul Huda & Madrasah Ibtidaiyah \\
\hline 18 & MI Baiturrahim & Madrasah Ibtidaiyah \\
\hline 19 & SMP Negeri 1 Sapeken & Junior high school \\
\hline 20 & MTs Abu Hurairah & Madrasah Tsanawiyah \\
\hline 21 & MTs Al-Ghuraba & Madrasah Tsanawiyah \\
\hline 22 & MTs Nurul Huda & Madrasah Tsanawiyah \\
\hline 23 & MTs Nurul Amien & Madrasah Tsanawiyah \\
\hline 24 & $\begin{array}{l}\text { Madrasah Aliyah Abu } \\
\text { Hurairah }\end{array}$ & Aliyah \\
\hline 25 & $\begin{array}{l}\text { Madrasah Aliyah Nurul } \\
\text { Amien }\end{array}$ & Aliyah \\
\hline 26 & $\begin{array}{l}\text { Madrasah Aliyah Al- } \\
\text { Ghuraba }\end{array}$ & Aliyah \\
\hline 27 & SMA Negeri 1 Sapeken & Senior high school \\
\hline
\end{tabular}

Source: Sapeken District Government May 2018

The development of education in the Sapeken archipelago, Sumenep, East Java can not be separated from the role of local leaders named KH. Ad-Dailamy Abu Hurairah who in writing the next article called AdDailamy. Ad-Dailamy was born from a family of religious leaders from the eastern region of Bugis, which is $\mathrm{KH}$.

\footnotetext{
${ }^{2}$ Fishermen who catch a kind of fish pindang, squid and cob by way of flockingone boat about six

people, usually leaving in the afternoon and back in the morning.

${ }^{3}$ Interview with Hasan in his residence, May 2, 2018.
} 
Abu Hurairah, later by the citizens of the islands known as Puang. After studying at Pesantren Persis Bangil under the care of Abdul Kadir Hassan, Ad-Dailamy returned to his native island of Sapeken, by teaching the average fisherman's children who were not literate in al-Qur'an or alphabet.

Ad-Dailamy started educational and teaching activities for the children of the fishermen under his house. At that time there is no classroom facilities and learning space that can be used to educate and teach children. Armed with a fighting spirit to advance the education of fisherman children Ad-Dailamy started. From time to time, the children who learn to study more and more, he finally moved to teach at the mosque which is located in the north of his house. Recitation activities did not stop at the children, he began to get students who want to learn from adults, both men and women.

The magnitude of the islanders' enthusiasm for learning is then answered by Ad-Dailamy by establishing a formal education institution, pesantren named after his father Abu Hurairah. Since 1976 the Pesantren Abu Hurairah officially stands and accepts students and students. In his journey, Abu Hurairah pesantren not only teach religious material, but also general education materials. It is realized by opening a formal education starting from madrasah ibtidaiyah, tsanawiyah and aliyah. Since its establishment until now, there have been thousands of alumni who successfully nurtured and educated by Ad-Dailamy through Pesantren Abu Hurairah who caretaker.

Among the alumni who successfully graduated many who later took part in educational institutions that exist in the Sapeken archipelago region, as well as other regions in Indonesia, either as educators or established educational institutions. Among the alumni who became educators and faculty, some were teaching at Pesantren Abu Hurairah himself, State Junior High School (SMPN) Sapeken, State Senior High School (SMAN) Sapeken, as well as other formal schools in the Sapeken archipelago. Not only as educators and teachers alone, the alumni of Pesantren Abu Hurairah many also established formal educational institutions on the islands in the archipelago of Sapeken.

From 11 villages in Sapeken, Sapeken Village, Paliat, Sabuntan, Saur-Saibus, Sasiil, Sepanjang, Tanjung Kiaok, Pagerungan Besar, Pagerungan Kecil, Sakala and Sadulang, villages and islands in the Sapeken islands graduates of Pesantren Abu Hurairah who founded and managed educational institutions, from non-formal to formal educational institutions at various levels. In addition to establishing educational institutions in the region of the Sapeken archipelago, the graduates of Pesantren Abu Hurairah also established many educational institutions in the archipelago and remote areas of the archipelago. Among the graduates of Pesantren Abu
Hurairah who founded educational institutions in Maluku, Kupang Nusa Tenggara Timur (NTT), and others ${ }^{4}$.

So the journey of education run by local figures on a remote island of Sapeken, Sumenep, East Java and then evolved and became the embryo of the birth of educational institutions in the archipelago and inland which became agents of change in improving qualityeducation of the nation's children. Of these schools are then also born to scholars and scholars who have been active in various educational institutions homeland. One of the alumni who successfully took part in educational institutions is Dr. Sudarman, who is Assistant Dean of the Faculty of Adab and Humanities of the State Islamic Institute (IAIN) Imam Bonjol Padang, West Sumatra ${ }^{5}$.

Table 2

Data dissemination graduates of Pesantren Abu Hurairah who established/ led educational institutions in Indonesia

\begin{tabular}{|c|l|l|l|}
\hline No & \multicolumn{1}{|c|}{$\begin{array}{c}\text { Name of } \\
\text { School }\end{array}$} & \multicolumn{1}{|c|}{ Locations } & \multicolumn{1}{|c|}{$\begin{array}{l}\text { Model of } \\
\text { Institutions }\end{array}$} \\
\hline 1 & $\begin{array}{l}\text { Abdullah } \\
\text { Mutaya }\end{array}$ & $\begin{array}{l}\text { Sepangkur } \\
\text { Besar, Sapeken }\end{array}$ & Pesantren \\
\hline 2 & Moh. Rawi & $\begin{array}{l}\text { Sepangkur } \\
\text { Besar, Sapeken }\end{array}$ & Pesantren \\
\hline 3 & Abdul Kadir & $\begin{array}{l}\text { Saur, Kecamatan } \\
\text { Sapeken }\end{array}$ & $\begin{array}{l}\text { Madrasah } \\
\text { Aliyah }\end{array}$ \\
\hline 4 & Shadiq & $\begin{array}{l}\text { Pagerungan } \\
\text { Kecil, Sapeken }\end{array}$ & Pesantren \\
\hline 5 & Yasir & $\begin{array}{l}\text { Pagerungan } \\
\text { Kecil, Sapeken }\end{array}$ & $\begin{array}{l}\text { Madrasah } \\
\text { Aliyah }\end{array}$ \\
\hline 6 & Taifur & $\begin{array}{l}\text { Pagerungan } \\
\text { Besar, Sapeken }\end{array}$ & $\begin{array}{l}\text { Madrasah } \\
\text { Aliyah }\end{array}$ \\
\hline 7 & Hosaini & $\begin{array}{l}\text { Paliat, Sapeken } \\
\text { Madrasah } \\
\text { Aliyah }\end{array}$ \\
\hline 8 & Zaidi & Sasiil, Sapeken & $\begin{array}{l}\text { Madrasah } \\
\text { Tsanawiyah }\end{array}$ \\
\hline 9 & Ahmad & $\begin{array}{l}\text { Sepanjang, } \\
\text { Sapeken }\end{array}$ & $\begin{array}{l}\text { Madrasah } \\
\text { Tsanawiyah }\end{array}$ \\
\hline 10 & Abd. Hamid & $\begin{array}{l}\text { Sepanjang, } \\
\text { Sapeken }\end{array}$ & $\begin{array}{l}\text { Madrasah } \\
\text { Tsanawiyah }\end{array}$ \\
\hline 11 & $\begin{array}{l}\text { Dhamim } \\
\text { Hasyima } \\
\text { Sapeken }\end{array}$ & $\begin{array}{l}\text { Pesantren } \\
\text { Sakala, Sapeken }\end{array}$ & $\begin{array}{l}\text { Madrasah } \\
\text { Tsanawiyah }\end{array}$ \\
\hline 12 & Moh. Said & $\begin{array}{l}\text { Madrasah } \\
\text { Aliyah }\end{array}$ \\
\hline 13 & Hamzahang & $\begin{array}{l}\text { Madrasah } \\
\text { ibtidaiyah }\end{array}$ \\
\hline 16 & Havangaini & Ambon, Maluku & Pesantren \\
\hline 17 & Junaidi Alfan & Solo, Central & Academy \\
\hline
\end{tabular}

${ }^{4}$ Interview Ahmad Nurdin, graduates of Pesantren Abu Hurairah who founded an educational institution inAmbon, July 19, 2018, by cellular phone.

${ }^{5}$ Interview Sudarman, graduates of Pesantren Abu Hurairah, July 19, 2018, by cellular phone. 
Table 2, cont.

\begin{tabular}{|c|c|c|c|}
\hline & & Java & \\
\hline 18 & $\begin{array}{l}\text { Busri } \\
\text { Abdullah }\end{array}$ & Ciputat, Banten & Pesantren \\
\hline 19 & Nur Asyur & Denpasar, Bali & Primary school \\
\hline 20 & $\begin{array}{l}\text { Abu } \\
\text { Hurairah }\end{array}$ & Denpasar, Bali & Primary school \\
\hline 21 & Umar & $\begin{array}{l}\text { Karangasem, } \\
\text { Bali }\end{array}$ & Pesantren \\
\hline 22 & Insan Kamil & Singaraja, Bali & Pesantren \\
\hline 23 & Ramli & Batam & Academy \\
\hline 24 & Bambang & $\begin{array}{l}\text { Malang, } \quad \text { East } \\
\text { Java }\end{array}$ & $\begin{array}{l}\text { Madrasah } \\
\text { Aliyah }\end{array}$ \\
\hline 25 & Walid & $\begin{array}{l}\text { Pulau } \\
\text { Dewakang, } \\
\text { Lompo }\end{array}$ & Pesantren \\
\hline 26 & Ida Zubaidah & $\begin{array}{ll}\text { Gowa, } & \text { South } \\
\text { Sulawesi } & \end{array}$ & Primary school \\
\hline 27 & $\begin{array}{l}\text { Firdausi } \\
\text { Zakir }\end{array}$ & $\begin{array}{l}\text { Palembang, } \\
\text { South Sumatera }\end{array}$ & Primary school \\
\hline 28 & Mustariyadi & $\begin{array}{l}\text { Pekalongan, } \\
\text { Central Java }\end{array}$ & Primary school \\
\hline 29 & Zainab & $\begin{array}{l}\text { Surabaya, East } \\
\text { Java }\end{array}$ & Primary school \\
\hline 30 & Rifki & $\begin{array}{l}\text { Sidoarjo, } \\
\text { Java }\end{array}$ & Kindergarten \\
\hline 31 & $\begin{array}{l}\text { Ahmad } \\
\text { Baihaqi }\end{array}$ & Bangil, Pasuruan & Primary school \\
\hline 32 & Rusli & Lombok & Pesantren \\
\hline 33 & Rustami & Central Jakarta & $\begin{array}{l}\text { Senior high } \\
\text { school }\end{array}$ \\
\hline 34 & Arwadi & $\begin{array}{l}\text { Bogor, West } \\
\text { Java }\end{array}$ & Primary school \\
\hline
\end{tabular}

Source: KH. Ad-Dailamy and various sources, processed July 2018

If studied using the theoretical angle of the theory, then the theory used to discuss the role of local leaders in the development of island communities education and remote areas in Indonesia is the theory of actors. According to Anselmus Toenlioe, in the paradigm of subjectivism, humans are actors who reconstruct social life. As an actor, man acts on the definition he sees in social reality, and transforms to social life (Toenlioe, 2016: 60).

Ad-Dailamy's involvement in social life, particularly education in the Sapeken archipelago, begins with his concern for educational conditions that have only formal education at the primary school level in only three locations, in an unkempt state, resulting in basic educationthe fishermen's children in the archipelago become dormant. His fishermen's children only play in a condition of not dressing and begging or asking fish to the fisherman with the term mamacciro ${ }^{6}$.

${ }^{6}$ Fishing activities conducted by children by visiting new fishing boatshome from fishing. Theobtained fish is then sold and used for snacks. 
established educational institutions on each island they originated or their hometown originated. In addition to spreading in the islands of the Sapeken archipelago, the alumni are widely spread in various parts of Indonesia to establish or lead educational institutions, through the program of devotion of alumni santri, which was originally devoted to the territory of kepualauan and remote in the homeland. But not a few who have completed the task of dedication, continuing education in high school and subsequently establishing educational institutions in each residence, as shown in second table ${ }^{9}$.

The ability of actors to influence others, by Peter Burke depends on the charisma of the actor. Burke, quoting Max Weber on charisma, as an individual's qualities for being endowed with abilities beyond the average human, or at least possessing extraordinary strength and quality (Burke, 2015: 136).

Ad-Dailamy as an actor has a charisma, because of his insistence in doing change action amidst apathetic society conditions and indifferent to the education of the younger generation of the archipelago. It is more evident after the residential house used for teaching and learning was burned by people who did not like the changes made by Ad-Dailamy. But there were no casualties for the incident. the charisma possessed by Ad-Dailamy was also growing stronger by the repressive actions of the regime at that time to stop him from educational activities undertaken. But the determination and strength of his determination can not be shaken, so that the public's faith is stronger against what he does and strives for. Public support is increasingly widespread and stronger, the parents who entrust santrinya in pesantren he founded more and more. As well as the construction of pesantren buildings mostly using self-help and community support consisting of fishermen. Until now, boarding school established by Ad-Dailamy has given birth thousands of alumni scattered in various corners of the country ${ }^{10}$.

Social change according to Selo Sumardjan, starting from the culture and education of a society. So the social changes that occur in the Sapeken archipelago society began from changes to education. Changes in education result in changes in patterns of behavior, attitudes, values, and groups within society. In other languages changes in the culture of society (Soemardjan, 1986: 303).

Nanang Martono mentions, social change will not occur suddenly, any social change in any form, must involve the actors who change social life, either partial changes, as well as a thorough change, or a sudden change, or long-term changes, entirely involving actors (Martono, 2012: 12). In this study, clearly changes in the Sapeken archipelago community can not be separated from the role of local leaders Kiai Ad-Dailamy, through changes in the

${ }^{9}$ Interview Dhamim Hasyima, graduates of Pesantren Abu Hurairah in residence, July 23, 2018.

${ }^{10}$ Interview Sahruddin, guardian santri Pesantren Abu Hurairah in residence, July 22, 2018. education sector which then continues to evolve in cultural changes as well as the life of island communities widely.

\section{CONCLUSION}

Social change always involves actors who are the main drivers of social change. The actor moves from a small neighborhood, then continues to grow larger and larger. such as shaping a wave of increasing change, and having a determinant impact on a society's change. One area that can change society is education. Through education, community change moves slowly but surely in a more advanced and civilized direction.

As an actor of change, KH. ad-Dailamy Abu Hurairah transformed fishing communities in the Sapeken archipelago with an educational path, beginning to educate four fishermen children, then continue to grow to hundreds of children, and continue to grow to establish pesantren and formal educational institutions in the year1976. The graduates who were born from Pesantren Abu Hurairah which he founded then spread across the island in the archipelago Sapeken, even then spread in various corners of the country. Initially they are many who educate educational institutions in remote and remote areas, but some time later not a few who are in the cities.

\section{REFERENCES}

Burke, P. (2015). History and Social Theory. (Translated from History and Social

Theory, Second Edition by Mestika Zed, Zulfami and A. Sairozi). Jakarta:

Pustaka Obor Indonesia.

Jones, P, et al. (2016). Introduction to Social Theories, from Theory of Functionalism to post-Modernism. (Translated from Introducing Social Theory, SecondEdition

by Achmad Fedyani Saifuddin). Jakarta: Pustaka Obor Indonesia.

Maliki, Z. (2012). Reconstruction of Modern Social

Theory. Yogyakarta: Gadjah Mada University Press.

Martono, N. (2012). Sociology of Social Change: Classical Perspectives, Modern,

Posmodern, and Poskolonial. Jakarta: Raja Grafindo Persada.

Prasetyo, E. (January 17, 2016). Portrait of Education in Disadvantaged Areas. Quoted fromwww. koransindo.com.

Rahman, A. (2018). "Bajo tribe and Poverty (Case Study of Poverty of Fishermen

Bajo Tribe in Saur Saibus Village, Sapeken SubDistrict, Sumenep Regency)."Quoted from http://digilib.uinsby.ac.id.

Toenlioe, A. (2016). Theory and Philosophy of Education. Malang: Gunung Samudera.

Widodo, H. (2015). "Portrait of Education in Indonesia and Readiness inFacing the 
Asian Economic Community (MEA)."Cendekia Journal, 13 (2), pp.294.

Wirawan, IB (2015). Social Theories in Three Paradigms (Social Facts, Definitions

Social and Social Behavior). Jakarta:

Prenadamedia Group.

Soemardjan, S. (1986). Social change in Yogyakarta.

Yogyakarta: Gadjah Mada

University Press.

- (2017). East Java Province In Figures 2017.

Quoted fromwww.jatim.bps.go.id. 